\title{
Hahella ganghwensis sp. nov., isolated from tidal flat sediment
}

Correspondence

Jongsik Chun

jchun@snu.ac.kr

\author{
Keun Sik Baik, ${ }^{1}$ Chi Nam Seong, ${ }^{1}$ Eun Mi Kim, ${ }^{1,2}$ Hana Yi, ${ }^{3}$ \\ Kyung Sook $\mathrm{Bae}^{4}$ and Jongsik Chun ${ }^{3}$
}

\author{
${ }^{1}$ Department of Biology, College of Natural Sciences, Sunchon National University, Sunchon \\ 540-742, Republic of Korea \\ ${ }^{2}$ Department of Dental Hygiene, Kwangyang Health College, Kwangyang 545-703, Republic of \\ Korea \\ ${ }^{3}$ School of Biological Sciences, Seoul National University, 56-1 Shillim-dong, Kwanak-gu, \\ Seoul 151-742, Republic of Korea \\ ${ }^{4}$ Laboratory of Insect Resources, Korea Research Institute of Bioscience and Biotechnology, \\ Yusung PO Box 115, Taejon 305-600, Republic of Korea
}

The genus Hahella was proposed by Lee et al. (2001) to accommodate a red-pigmented marine bacterial strain that formed a distinct phyletic line within the $\gamma$-Proteobacteria with low $(<90 \%)$ 16S rRNA gene sequence similarity to other recognized bacterial species. The only species of the genus, Hahella chejuensis, was isolated from a marine sediment sample from Korea (Marado, Cheju) and produced abundant extracellular polysaccharides. During the course of a study on marine microbial diversity, a Hahellalike strain, designated FR $1050^{\mathrm{T}}$, was isolated from a Korean sediment sample and was the subject of a taxonomic investigation. Based on its polyphasic properties, strain $\mathrm{FR} 1050^{\mathrm{T}}$ is considered to represent a novel species, for which the name Hahella ganghwensis sp. nov. is proposed.

A marine sediment sample was collected from the getbol (Korean tidal flat) of Ganghwa Island, Korea ( $37^{\circ} 35^{\prime} 31 \cdot 9^{\prime \prime} \mathrm{N}$ $\left.126^{\circ} 27^{\prime} 24 \cdot 5^{\prime \prime} \mathrm{E}\right)$. The sample was diluted with sterilized artificial sea water (ASW; Lyman \& Fleming, 1940), spread onto a plate that contained marine agar 2216 (MA; Difco) and incubated at $25^{\circ} \mathrm{C}$ for 3 weeks. The isolate was routinely

Published online ahead of print on 4 October 2004 as DOI 10.1099/ ijs.0.63411-0.

The GenBank/EMBL/DDBJ accession number for the 16S rRNA gene sequence of strain FR1050 ${ }^{\top}$ is AY676463. cultured on MA and maintained as a glycerol suspension $(20 \%, \mathrm{w} / \mathrm{v})$ at $-80^{\circ} \mathrm{C}$. H. chejuensis KCTC $2396^{\mathrm{T}}$ cultured on MA at $30^{\circ} \mathrm{C}$ was used as a reference strain.

16S rRNA gene sequence analysis of strain FR $1050^{\mathrm{T}}$ was performed using universal primers (Lane, 1991) as described by Chun \& Goodfellow (1995), and an almost complete sequence was obtained (1454 bp). Phylogenetic analyses were performed using the Fitch-Margoliash (Fitch \& Margoliash, 1967), maximum-likelihood (Felsenstein, 1993), maximum-parsimony (Fitch, 1971) and neighbour-joining (Saitou \& Nei, 1987) methods. Evolutionary distance matrices were generated according to Jukes \& Cantor (1969). The resulting neighbour-joining tree topology was evaluated by bootstrap analyses (Felsenstein, 1985) based on 1000 resamplings. Alignment and phylogenetic analyses were carried out using the jPHYDIT program (available at http://chunlab.snu.ac.kr/jphydit/) and PAUP 4.0 (Swofford, 1998) as described by Chun et al. (2000). Preliminary sequence comparison against the $16 \mathrm{~S}$ rRNA gene sequences held in GenBank indicated that the getbol isolate belonged to the $\gamma$-Proteobacteria. The resultant sequence was then aligned manually based on $16 \mathrm{~S}$ rRNA gene sequence secondary structure (Gutell, 1994) with representative sequences of the $\gamma$-Proteobacteria obtained from GenBank. Only unambiguously aligned nucleotide positions (1381 bp) 


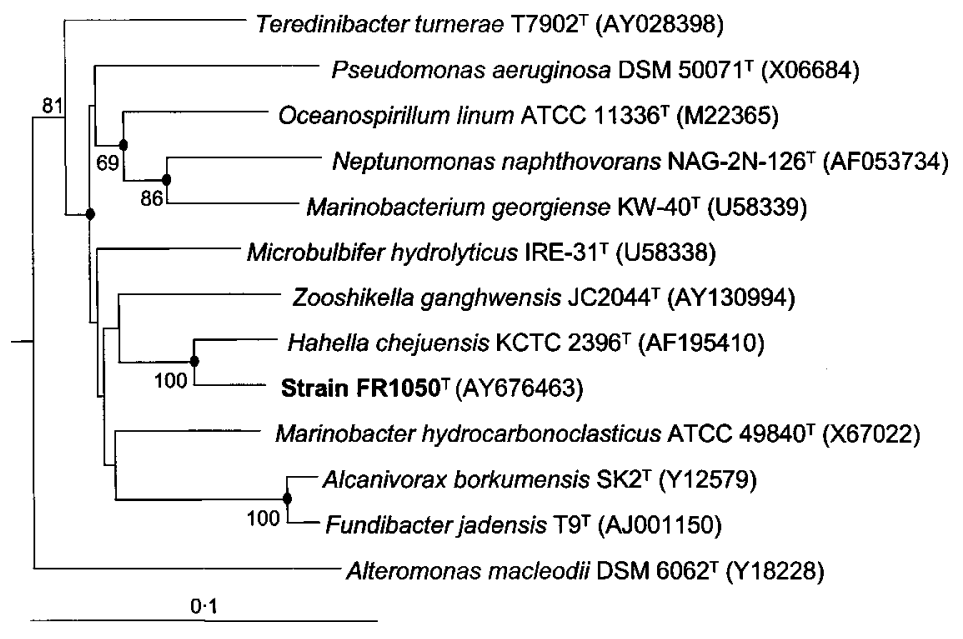

Fig. 1. Neighbour-joining tree based on nearly complete $16 \mathrm{~S}$ rRNA gene sequence analysis showing relationships between strain FR $1050^{\top}$ and members of the $\gamma$ Proteobacteria. Numbers at nodes indicate percentages of bootstrap support (>50\%) based on 1000 resamplings. Solid circles indicate that the corresponding nodes (groupings) were also recovered in FitchMargoliash, maximum-likelihood and maximumparsimony trees. Helicobacter pylori ATCC $43504^{\top}$ (U01330) was used as an outgroup (not shown). Bar, $0 \cdot 1$ nucleotide substitution per position.

were used to construct phylogenetic trees. On the basis of 16S rRNA gene sequence similarity values, the closest relatives were $H$. chejuensis KCTC $2396^{\mathrm{T}}(94 \cdot 7 \%)$, Zooshikella ganghwensis JC2044 ${ }^{\mathrm{T}}(90 \cdot 1 \%)$ and Microbulbifer hydrolyticus DSM $11525^{\mathrm{T}}(90 \cdot 7 \%)$. No other recognized bacterial species showed more than $90 \% 16 \mathrm{~S}$ rRNA gene sequence similarity. This close relationship between strain FR $1050^{\mathrm{T}}$ and $H$. chejuensis KCTC $2396^{\mathrm{T}}$ was also evident in the phylogenetic trees (Fig. 1). Strain FR1050 ${ }^{\mathrm{T}}$ and $H$. chejuensis formed a monophyletic clade with $100 \%$ bootstrap support and this grouping was recovered in all the phylogenetic trees employed in this study. Z. ganghwensis $\mathrm{JC} 2044^{\mathrm{T}}$ was recovered as a sister group to the Hahella clade containing strain FR $1050^{\mathrm{T}}$ in the neighbour-joining, Fitch-Margoliash and maximum-likelihood trees. However, the branching patterns of the other genera varied depending on the tree-building methods employed and were supported by relatively low bootstrap values. It is evident from phylogenetic analysis that strain FR $1050^{\mathrm{T}}$ is affiliated to the genus Hahella with a novel species status.

For phenotypic tests, strain FR $1050^{\mathrm{T}}$ and H. chejuensis KCTC $2396^{\mathrm{T}}$ were grown on $\mathrm{MA}$ at $30^{\circ} \mathrm{C}$. Cellular morphologies were observed by differential interference microscopy (Nikon) and scanning electron microscopy (JEOL) using cells grown at $25^{\circ} \mathrm{C}$ for 3 days. Motility was examined using wet mounts. The $\mathrm{pH}$ range (3-12) for growth was determined using MA. The requirement for $\mathrm{NaCl}(0-10 \%)$ and sea salts (0-11\%, Sigma) for growth was tested using synthetic ZoBell medium (ZoBell, 1941; 15 g Bacto agar, $5 \mathrm{~g}$ Bacto peptone, $1 \mathrm{~g}$ yeast extract, $0 \cdot 1 \mathrm{~g}$ ferric citrate in $1000 \mathrm{ml}$ distilled water). Sea salts were not added to the synthetic medium when the growth range for $\mathrm{NaCl}$ concentration was tested. The getbol isolate was halophilic, requiring media containing $1-10 \%(\mathrm{w} / \mathrm{v})$ artificial sea salts for growth (optimum 4-6\%), and was unable to grow on ZoBell medium containing $0-10 \%(\mathrm{w} / \mathrm{v}) \mathrm{NaCl}$ alone. Growth at various temperatures was examined on MA at 4-50 ${ }^{\circ} \mathrm{C}$. Growth under anaerobic conditions was checked in an anaerobic chamber $\left(1 \% \mathrm{CO}_{2}, 10 \% \mathrm{H}_{2}, 80 \% \mathrm{~N}_{2}\right.$; Sheldon Manufacturing) using anaerobically prepared MA, trypticase soy agar (Difco; supplemented with $1 \%$ sea salts) and nutrient agar (Difco; supplemented with $1 \%$ sea salts). Biochemical tests were performed using the API 20NE, API 20E and API ZYM kits (bioMérieux). Strips were inoculated with a heavy bacterial suspension in ASW or AUX medium (bioMérieux) supplemented with $2 \%$ sea salts. Catalase and oxidase activities were determined using $3 \%(\mathrm{v} / \mathrm{v})$ hydrogen peroxide and Kovacs reagent (Kovacs, 1956), respectively. Results from these biochemical and physiological tests are given in the species description and in Table 1. In contrast to the result given by Lee et al. (2001), the type strain of H. chejuensis, together with strain $\mathrm{FR} 1050^{\mathrm{T}}$, showed no growth under anaerobic conditions when the media were prepared anaerobically. The reported anaerobic growth of $H$. chejuensis may have resulted from residual oxygen in the media tested by Lee et al. (2001). Based on the result obtained here, an emended description for the genus Hahella is given below.

Cellular fatty acids of strain FR $1050^{\mathrm{T}}$ and $H$. chejuensis KCTC $2396^{\mathrm{T}}$ were analysed as methyl esters by GLC according to the instructions of the Microbial Identification System (MIDI). Fatty acid methyl esters were prepared from biomass grown on MA at $30^{\circ} \mathrm{C}$ for 2 days. The DNA $\mathrm{G}+\mathrm{C}$ content was determined by thermal denaturation as described by Mandel \& Marmur (1968). The DNA G+C ratio of strain FR $1050^{\mathrm{T}}$ was $44 \mathrm{~mol} \%$ and the cellular fatty acid profile is given in Table 2. Although the culture conditions for growth of strain FR $1050^{\mathrm{T}}$ and H. chejuensis KCTC $2396^{\mathrm{T}}$ were identical, their fatty acid compositions were very different, especially for $\mathrm{C}_{18: 1} \omega 7 c, \mathrm{C}_{18: 1} \omega 9 c, \mathrm{C}_{17: 0}$ 10-methyl and a mixture of iso- $\mathrm{C}_{16: 0} 2 \mathrm{OH}$ and/or $\mathrm{C}_{16: 1} \omega 7 c$.

Our phylogenetic analysis indicates that strain FR1050 ${ }^{\mathrm{T}}$ is affiliated to the genus Hahella. However, the low $16 \mathrm{~S}$ rRNA gene sequence similarity between strain FR1050 ${ }^{\mathrm{T}}$ and $H$. chejuensis KCTC $2396^{\mathrm{T}}(94 \cdot 7 \%)$ indicates that the getbol isolate represents a different species. In addition, many phenotypic characteristics differentiate strain FR1050 ${ }^{\mathrm{T}}$ from $H$. chejuensis (Tables 1 and 2). Based on the polyphasic evidence presented here, the getbol isolate merits novel 
Table 1. Phenotypic characteristics that differentiate strain FR1050 ${ }^{\top}$ from $H$. chejuensis

+ , Positive; -, negative; W, weakly positive. Both strains were positive for catalase, oxidase, hydrolysis of aesculin and gelatin, alkaline phosphatase, esterase (C4), esterase lipase (C8), leucine arylamidase, acid phosphatase, naphthol-AS-BI-phosphohydrolase and utilization of D-glucose and mannose; negative for arginine dihydrolase, lysine decarboxylase, ornithine decarboxylase, production of acetoin, trypsin, $\alpha$-chymotrypsin, $\alpha$-galactosidase, $\beta$-galactosidase, $\beta$-glucuronidase, $N$-acetyl- $\beta$-glucosaminidase, $\alpha$ mannosidase, $\alpha$-fucosidase, indole, urease, production of $\mathrm{H}_{2} \mathrm{~S}$, tryptophan deaminase and utilization of rhamnose, melibiose and arabinose. Data are from this study and Lee et al. (2001).

\begin{tabular}{|lcc|}
\hline Characteristic & $\begin{array}{c}\text { Strain } \\
\text { FR1050 }^{\text {T }}\end{array}$ & H. chejuensis \\
\hline Pigmentation & Cream & Red \\
Temperature range for growth $\left({ }^{\circ} \mathrm{C}\right)$ & $15-40$ & $10-45$ \\
Sea salts requirement & + & - \\
Nitrate reduction & - & + \\
Acid production from glucose & - & + \\
Utilization of: & & \\
Citrate & W & - \\
D-Mannitol & - & + \\
D-Sorbitol & - & + \\
Inositol & - & + \\
Malate & + & - \\
Maltose & - & + \\
Sucrose & - & + \\
Enzyme activity (API ZYM): & & \\
Lipase (C14) & + & W \\
Valine arylamidase & W & + \\
Cystine arylamidase & - & W \\
$\alpha$-Glucosidase & + & - \\
$\beta$-Glucosidase & - & W \\
DNA G + C content (mol\%) & 44 & 55 \\
& & \\
\hline
\end{tabular}

species in the genus Hahella. The name Hahella ganghwensis sp. nov. is therefore proposed for strain FR $1050^{\mathrm{T}}$.

\section{Description of Hahella ganghwensis sp. nov.}

Hahella ganghwensis (gang.hwen'sis. N.L. fem. adj. ganghwensis pertaining to Ganghwa Island, Republic of Korea, the geographical origin of the type strain of the species).

Gram-negative, oxidase- and catalase-positive, aerobic and halophilic. Colonies on MA are circular, smooth, convex with entire margin, slightly cream-coloured and approximately $1 \mathrm{~mm}$ in diameter after 5 days at $30^{\circ} \mathrm{C}$. Produces slightly brown pigment after 5 days on MA at $40^{\circ} \mathrm{C}$. Cells are motile rods, $0 \cdot 4-0 \cdot 5 \times 1 \cdot 0-1 \cdot 5 \mu \mathrm{m}$ in size. Spores are not formed. Growth occurs in 1-10\% (w/v) sea salts (optimum $4-6 \%)$. Does not grow without sea salts. Growth occurs at pH 5-10 (optimum 7-8) and at $15-40^{\circ} \mathrm{C}$ (optimum $35^{\circ} \mathrm{C}$ ). Utilizes $\mathrm{N}$-acetylglucosamine, but not amygdalin, gluconate, caprate or adipate. Other physiological and biochemical
Table 2. Cellular fatty acid composition (\%) of strain FR1050

Only fatty acids representing at least $1 \%$ of the total fatty acids are presented. -, Not detected.

\begin{tabular}{|c|c|c|}
\hline Fatty acid & Strain FR1050 ${ }^{\mathrm{T}}$ & H. chejuensis \\
\hline \multicolumn{3}{|l|}{ Saturated fatty acids } \\
\hline $\mathrm{C}_{12: 0}$ & $2 \cdot 4$ & $1 \cdot 3$ \\
\hline $\mathrm{C}_{14: 0}$ & $2 \cdot 4$ & $2 \cdot 8$ \\
\hline $\mathrm{C}_{16: 0}$ & $18 \cdot 1$ & $12 \cdot 5$ \\
\hline $\mathrm{C}_{16: 0} \mathrm{~N}$ alcohol & $7 \cdot 2$ & $6 \cdot 5$ \\
\hline $\mathrm{C}_{18: 0}$ & $1 \cdot 1$ & $2 \cdot 8$ \\
\hline \multicolumn{3}{|l|}{ Unsaturated fatty acids } \\
\hline $\mathrm{C}_{16: 1} \omega 9 c$ & $8 \cdot 8$ & $3 \cdot 2$ \\
\hline $\mathrm{C}_{17: 1} \omega 8 c$ & $1 \cdot 4$ & - \\
\hline $\mathrm{C}_{18: 1} \omega 7 c$ & $<1$ & $9 \cdot 4$ \\
\hline $\mathrm{C}_{18: 1} \omega 9 c$ & $39 \cdot 0$ & $19 \cdot 8$ \\
\hline $\mathrm{C}_{18: 3} \omega 6 c$ & $9 \cdot 0$ & $10 \cdot 7$ \\
\hline \multicolumn{3}{|l|}{ Hydroxy fatty acid } \\
\hline $\mathrm{C}_{12: 0} 3-\mathrm{OH}$ & $3 \cdot 8$ & $2 \cdot 5$ \\
\hline \multicolumn{3}{|l|}{ Methyl fatty acid } \\
\hline $\mathrm{C}_{17: 0} \quad 10$-methyl & - & $14 \cdot 4$ \\
\hline \multicolumn{3}{|l|}{ Summed feature ${ }^{\star}$} \\
\hline 3 (iso- $\mathrm{C}_{16: 0} 2-\mathrm{OH} / \mathrm{C}_{16: 1} \omega 7 c$ ) & $3 \cdot 3$ & $11 \cdot 9$ \\
\hline
\end{tabular}

${ }^{\star}$ Summed features are groups of two or three fatty acids that could not be separated by GLC with the MIDI system.

characteristics are given in Table 1 . Major fatty acids are $\mathrm{C}_{18: 1} \omega 9 c(39 \cdot 0 \%)$ and $\mathrm{C}_{16: 0}(18 \cdot 1 \%)$; the complete fatty acid profile is given in Table 2. The DNA G $+\mathrm{C}$ content is $44 \mathrm{~mol} \%$.

The type strain, FR $1050^{\mathrm{T}}\left(=\mathrm{KCTC} 12277^{\mathrm{T}}=\mathrm{JCM} 12486^{\mathrm{T}}\right)$, was isolated from sediment of getbol, the Korean tidal flat.

\section{Emended description of the genus Hahella}

The description of the genus Hahella remains that given by Lee et al. (2001), with the following modifications. Aerobes. Reduction of nitrate to nitrite is variable. Require sea salts or $\mathrm{NaCl}$ for growth.

\section{Acknowledgements}

This work was supported by the 21C Frontier Microbial Genomics and Applications Center Program (grant MG02-0101-001-2-1-0). We thank Dr Hong kum Lee (Korea Ocean Research \& Development Institute) for the gift of the type strain of Hahella chejuensis and also E. Y. Moon for help with physiological tests.

\section{References}

Chun, J. \& Goodfellow, M. (1995). A phylogenetic analysis of the genus Nocardia with $16 \mathrm{~S}$ rRNA gene sequences. Int J Syst Bacteriol 45, 240-245. 
Chun, J., Bae, K. S., Moon, E. Y., Jung, S. O., Lee, H. K. \& Kim, S. J. (2000). Nocardiopsis kunsanensis sp. nov., a moderately halophilic actinomycete isolated from a saltern. Int J Syst Evol Microbiol 50, 1909-1913.

Felsenstein, J. (1985). Confidence limits on phylogenies: an approach using the bootstrap. Evolution 39, 783-791.

Felsenstein, J. (1993). PHYLIP (Phylogeny Inference Package), version 3.5c. Distributed by the author. Department of Genetics, University of Washington, Seattle, USA.

Fitch, W. M. (1971). Toward defining the course of evolution: minimum change for a specific tree topology. Syst Zool 20, 406-416.

Fitch, W. M. \& Margoliash, E. (1967). Construction of phylogenetic trees: a method based on mutation distances as estimated from cytochrome $c$ sequences is of general applicability. Science 155, 279-284.

Gutell, R. R. (1994). Collection of small subunit (16S- and 16S-like) ribosomal RNA structure: 1994. Nucleic Acids Res 22, 3502-3507.

Jukes, T. H. \& Cantor, C. R. (1969). Evolution of protein molecules. In Mammalian Protein Metabolism, vol. 3, pp. 21-132. Edited by H. N. Munro. New York: Academic Press.
Kovacs, N. (1956). Identification of Pseudomonas pyocyanea by the oxidase reaction. Nature 178, 703.

Lane, D. J. (1991). 16S/23S rRNA sequencing. In Nucleic Acid Techniques in Bacterial Systematics, pp. 115-175. Edited by M. Goodfellow. Chichester: Wiley.

Lee, H. K., Chun, J., Moon, E. Y., Ko, S. H., Lee, D. S., Lee, H. S. \& Bae, K. S. (2001). Hahella chejuensis gen. nov., sp. nov., an extracellular-polysaccharide-producing marine bacterium. Int J Syst Evol Microbiol 51, 661-666.

Lyman, J. \& Fleming, R. H. (1940). Composition of sea water. J Mar Res 3, 134-146.

Mandel, M. \& Marmur, J. (1968). Use of ultraviolet absorbance temperature profile for determining the guanine plus cytosine content of DNA. Methods Enzymol 12B, 195-206.

Saitou, N. \& Nei, M. (1987). The neighbor-joining method: a new method for reconstructing phylogenetic trees. Mol Biol Evol 4, 406-425.

Swofford, D. L. (1998). PAUP - Phylogenetic Analysis Using Parsimony, version 4. Sunderland, MA: Sinauer Associates.

Zobell, C. E. (1941). Studies on marine bacteria. I. The cultural requirements of heterotrophic aerobes. J Mar Res 4, 42-75. 